\title{
Analyzing Factors Affecting GRDP in Indonesia Using Spatial Panel Data Model
}

\author{
Mertha Endah Ervina ${ }^{1,2}$ \& I Gede Nyoman Mindra Jaya ${ }^{1}$ \\ ${ }^{1}$ Department of Statistics, Universitas Padjadjaran, Bandung, Indonesia \\ ${ }^{2}$ BPS-Statistics Indonesia, Indonesia \\ Correspondence: Mertha Endah Ervina, Department of Statistics, Universitas Padjadjaran, Bandung 40132, \\ Indonesia. E-mail: merthiez@gmail.com
}

Received: October 27, 2018

Accepted: November 5, 2018

Online Published: December 15, 2018

doi:10.5539/mas.v13n1p148

URL: https://doi.org/10.5539/mas.v13n1p148

The research is financed by BPS-Statistics Indonesia.

\begin{abstract}
Each region in Indonesia has diverse economic growth. Various empirical studies focus on this problem and attempt to identify the factors that affecting Gross Regional Domestic Product (GRDP) at constant prices or economic growth. However, the research on GRDP at constant prices or economic growth is not solely enough on observation units in a certain time (cross-section); these units also need to be observed in several periods of time. Moreover, the existence of spatial dependencies, which usually occur on the objects observed in form of regions or locations, causes estimation with OLS generating biased and inconsistent results. This study aims to analyze the factors that affecting GRDP at constant prices, namely population, original local government revenue, government expenditure, domestic investment, foreign investment, and the total manpower using the spatial panel data model with the quasi-maximum likelihood estimation method. This study is a quantitative study with panel data of 33 provinces in Indonesia during 2010-2016 periods. The best model obtained from these data was the Spatial Lag Fixed Effect Model with five independent variables. The referred variables are the number of populations, original local government revenue, government expenditure, domestic investment, and foreign investment which have a positive and also significant influence on GRDP at constant prices of provinces in Indonesia, while the total manpower do not have significant influence.
\end{abstract}

Keywords: economic growth, GRDP at constant prices, quasi-maximum likelihood, spatial lag fixed effect, spatial panel data

\section{Introduction}

Economic growth is one of the indicators to measure national development level of success. The economic growth of an area is measured using the growth of Gross Regional Domestic Product (GRDP) at Constant Prices. Some regions have higher economic growth than other regions. Thus, many empirical studies focus on this problem and try to identify the factors that influence GRDP at constant prices or economic growth.

Common method used to analyse variables affecting GRDP at constant prices or economic growth is multiple linear regression. However, the research of GRDP at constant prices or economic growth can not only be done to cross sectional observation units, but these units also need to be observed over periods of time. Combination data of cross-sectional data with time series data is called panel data.

Baltagi (2008) as cited in Eliana (2016) states that there are several advantages in using panel data, namely data that is heterogeneous, more informative, greater degrees of freedom, superior in studying dynamic change, more capable in detecting and measuring influences that cannot be observed on pure cross-sectional data and pure time series. For example; to determine whether domestic investment can increase or decrease the GRDP at constant prices can be identified by observing an area before and after the domestic investment. Furthermore, the characteristics of the region are considered permanent so it can be seen whether the domestic investment will affect the GRDP at constant prices and how strong the influence will be.

One of the assumptions needed in the regression with ordinary least square (OLS) estimation method is that each 
observation must be mutually independent of one another. However interactions between regions must occur in regional economic analysis such as analysis on GRDP at constant prices. This is because the economy in a region is strongly influenced by surrounding economic activities, one of which is production factors supply from the surrounding area. Not to mention the development of infrastructure and information technology that ease interregional economic transactions. Ullman (1987) as cited in Haviliana (2017) stated that there are three factors influencing the interaction between regions, namely:

a) The existence of regional complementarity that occurs in different regions with limitations or surplus resources capacity between regions in resources and areas with resource deficits,

b) The existence of opportunities for intervening is the factors that prevent inter-regional interaction, thus it should be filled by other regions to comply their needs.

c) The ease of transfer or spatial transfer ability is the ease of transfer in space whether in the form of humans, ideas or information. This is influenced by the absolute and relative distance between regions, costs of transportation or transportation between regions, transport ease.

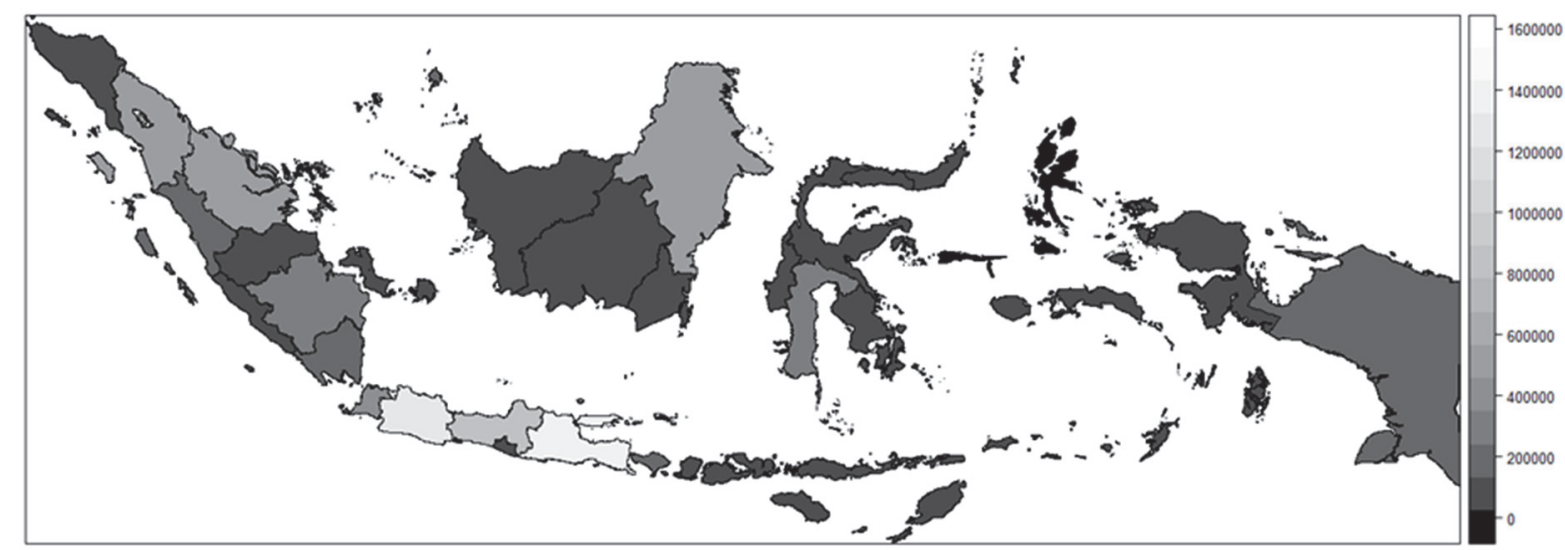

Figure 1. GRDP at Constant Prices 2016

On figure 1, it can be seen that the great value of GRDP at constant prices of the provinces in Indonesia that have geographical proximity with similar values (seen from similar colors). It indicates that the provincial GRDP at constant prices's value is not mutually independent but there is spatial dependence. According to LeSage and Pace (2009), spatial dependence reflects a situation in which the values observed in a location or region are affected by the observation values of the nearest neighbor.

In data with spatial dependencies that usually occur in observation objects namely regions or locations, estimation with OLS will result in biased and inconsistent estimates (LeSage \& Pace, 2004, 2008). The spatial panel data model involving space and time dimensions creates a possibility to take spatial dependence into account.

Parameter estimation method used in spatial panel data regression is not different from the estimation method used in spatial regression with cross-sectional data. Among the estimation methods, there is maximum likelihood method. Edi (2012) stated that the maximum likelihood method requires similar distribution of errors, that is normal $\left(0, \sigma^{2}\right)$ in the estimation process. Meanwhile in some cases, the error term sometimes does not follow the normal distribution. To fix this, data transformation is usually taken into account until the normality assumption is fulfilled so the inference estimator being done is correct. However, to get the appropriate transformation, experience difficulties are inevitable. Therefore Lee (2004) as cited in Edi (2012) offered the application of a quasimaximum likelihood (QML) method for spatial autoregressive which the error assumption does not follow normal distribution $\left(0, \sigma^{2}\right)$.

Based on that remark, the formulation of the research problem is:

1. What is appropriate panel data regression model used for GRDP at constant prices data and the affecting factors in provinces in Indonesia with period 2010-2016? factors affecting it

2. What is the form of spatial dependency on the data?

3. Is the residual from the formed spatial panel data model normally distributed $\left(0, \sigma^{2}\right)$ ? 
4. Partially, do the numbers of population, original local government revenue, government expenditure, domestic investment, foreign investment, and the total manpower have a significant influence toward GRDP at constant prices in Indonesia 2010-2016?

5. What is the best spatial data model for the GRDP at constant prices in Indonesia for 2010-2016?

\section{Theoretical Framework}

\subsection{Economic Growth}

The rate of economic growth indicates one's country/region success level in increasing economic output over time. Sutomo (2015) stated that the rate of economic growth calculated from the amount of GDP/GRDP with condition that the current prices is considered to be insufficient due to economic development of a country/region from one year to another is also affected by fluctuation of prices. In order for GDP/GRDP to be able to measure the real economic growth, the influence of price fluctuation in GDP/GRDP needs to be overcome, and this condition can be achieved by calculating the economic growth rate of GDP/GRDP in constant prices basis. Changes in GDP/GRDP value toward constant prices indicate change in the quantity of goods and services produced during the observation period.

There are several theories in regard with economic growth. These theories of economic growth reflect to the interconection between economic growth and the determinants of economic growth. The difference between one theory and another lies in the difference in focus of the discussion and or assumptions used (Rahardja \& Manurung, 2014).

\subsubsection{Classical Views}

Adam Smith was a pioneer in Classical economic thought. Muchtolifah (2010) stated that Smith in his book: "An Inquiry into the Nature and Causes of Wealth of Nations", which was published more than two centuries ago, stating some of his views about important factors in economic growth.

According to Adam Smith as cited in Chalid (2015), the growth process will occur simultaneously and have a relationship with one another. The emergence of improved performance in one sector will increase the attractiveness of capital accumulation, encourage technological advancement, increase specialization, and expand markets. This will encourage economic growth to increase rapidly. The process of money economic growth is an objective function which at the end it is dominated by constrained optimization; and that are the limited natural and human resources. If the condition of natural resources and skills of the population is no longer able to compensate ongoing economic activity, then economic growth will begin to experience a slowdown.

Malthus and Ricardo analyzed the impact of population growth on economic development. Malthus argued in the beginning, namely when the ratio between other production factors and the population / labor was relatively high (meaning that the population was relatively small when it is compared to other production factors), population growth and labor would increase the level of prosperity among community. However, if the population / labor are exceeding the other production factors, population growth will reduce per capita production and the level of community prosperity. Thus, population growth that continues to grow and does not along with resources growth will drag the community prosperity back to the subsystem level (a very low per capita income) (Muchtolifah, 2010).

If it is compared to this theoretical view with the development of the world economy since the early of the previous century, this prediction is not fully precise. Developed countries have made different progress apart from Malthus's predictions. This rapid development was mainly due to the introduction of technological developments and the increase of capital goods which the rate exceeds population growth. This was not predicted by Malthus and Ricardo (Muchtolifah, 2010).

\subsubsection{Schumpeter's View}

Schumpeter (1908) as cited in Muchtolifah (2010) stated that economic growth will not constantly grow, but there will be a time when it grows up or down. The conjuncture is caused by the activities of entrepreneurs in innovating or updating their activities in producing goods and giving services. To realize this kind of innovation, investment will be made and this investment will increase the economic activity. This process creates a multiplier process which leads to a further improvement and a more rapid growth of economic activity. In regard to that point, if entrepreneurs do not invest enough the economic activity will eventually decline. The economic growth will take a positive uprise if the entrepreneurs create innovations that will encourage investment, develop economic activities, and increase national production.

\subsubsection{Harrod-Domar Theory}


Harrod-Domar Theory was developed separately in the same period by E.S.Domar from United States and R.F.Harrold from England. Both Domar and Harrold believe that economic growth is determined by the rate of savings and investment. If the rate of savings and investment is considerabely low, the economic growth of the community and the country will also low. Furthermore, this correlation between economic growth, savings, and invesment is formulated in Harrold-Domar theory which is still known to this day (Chalid, 2015).

\subsubsection{Neo-Classical Theory}

Neo-Classical growth theory was first developed by Professor Robert Solow, who won the Nobel Prize in 1987 for his theory. His theory was published in February 1956 issue of the Quarterly Journal of Economics, in a paper entitled: A Contribution of the Theory of Economic Growth (Muchtolifah, 2010). Widjajanta, Widyaningsih, and Tanuatmodjo (2009) stated that this theory was a refinement of previous Classical theories. The focus discussion of neo-classical growth theory is the accumulation of capital goods stock and its relationship to the community's decision to save or invest. The assumptions of this theory include:

1) The level of technology is considered to be constant (no technology advancement);

2) The depreciation rate is considered to be constant;

3) No foreign trade or capital inflow;

4) There is no government sector;

5) The rate of population growth (labor) is also considered constant.

\subsubsection{Endojenus Growth Theory}

The theory developed by Romer (1986) is the latest development of the Classic to Neo Classical growth theory. The weakness of the Classical and Neo Classic models lies in the assumption that technology is exogenous. The consequence of this assumption is the occurrence of The Law of Diminishing Return, because technology is considered as a fixed input factor. Additionally, the more serious consequence of treating technology as an exogenous and constant factor is that the advanced and grown economy, in long term, it will be overwhelmed by a lower economy condition as long as the population growth rates, savings rates, and access toward technology are equal (Rahardja \& Manurung, 2014).

\subsection{Previous Study}

Research on the factors that influence GRDP or economic growth actually has been done before. Suindyah D (2011) based on her research on East Java's economic growth data in 2003-2010 using multiple linear regression analysis, concluded that: (1) By the increasing rate of investment in East Java, especially foreign investment, it will increase the economic growth, (2) total manpower will have a significant effect on the increasing economic growth, (3) the amount of government expenditure will support local development, especially economic development in East Java. This is because by the increasing amount of government expenditure, it will also increase the economic growth.

Sumardi (2016) using the Bayesian Averaging Model (BMA) method on the 2013 GRDP at constant prices data concluded that the variables that significantly influence the GRDP at constant prices in Indonesia in 2013 were original local government revenue, domestic investment, foreign investment, and total manpower. Investment variables and total manpower are significant as in the research conducted by Pambudi and Miyasto (2013) with panel data analysis methods, and Prok (2015) with multiple linear regression analysis methods.

Lestari (2015) using the bayesian geographically weighted regression method on GRDP per capita data in East Java 2013 found that variables that significantly affect the economic growth in East Java in 2013 were original local government revenue, government capital expenditure, domestic investment, and Labor Force Participation Rate (LFPR). On West Kalimantan GRDP data in 2004-2013, an analysis using spatial data panel method was conducted by Pratama, Kusnandar, and Rizki (2018). Government consumption and domestic investment variables proved to significantly increase the GRDP value in regency or cities in West Kalimantan. Meanwhile, the results of a research by Diputra, Sadik, and Angraini (2012) using the same method, that is spatial data panel, concluded that population is a significant variable that affect GRDP data in Jambi in 2000-2008.

\subsection{Hypothesis}

Based on previous theories and researches, the hypotheses proposed in this study are: population, original local government revenue, government expenditure, domestic investment, foreign investment, and total manpower, are believed to have a significant and positive influence toward GRDP at constant prices of all provinces in Indonesia. 


\section{Method}

\subsection{Data}

The data used are secondary data taken from BPS-Statistics Indonesia. The data used includes: GRDP at constant prices, population, original local government revenue, government expenditure, domestic investment, foreign investment, and total manpower. The boundaries of the study area are all provinces in Indonesia, namely 33 provinces, with series of data from 2010 to 2016 with a total observation of 231 units.

\subsection{Operasional Definition}

1) GRDP at Constant Prices

GRDP or Gross Regional Domestic Product is the sum of total value added produced by all economic industries (activities) in a given period (BPS, 2018). GRDP at Constant Prices is compiled based on prices in 2010 and aims to measure economic growth. The unit used is billion rupiah.

2) Population

Population includes all residents of the entire geographic territory of Renewtemplate of Indonesia, who have stayed for six months or longer, and those who intended to stay even though their length of stay was less then six months (BPS, 2018). The unit used is thousands of people.

3) Original Local Government Revenue (OLGR)

Original local government revenue is revenue derived from regional income that is coming from local taxes, regional retribution, the share of BUMD profits, revenues from services, and other revenues. The unit used is million rupiah.

4) Government Expenditure (GE)

Government expenditures are included in all types of expenditures and financing carried out by the government, such as personnel expenditures, goods and services expenditures, and capital expenditure. The unit used is million rupiah.

5) Domestic Invesment (DI)

Domestic investment means an investing activity to do business in the territory of the state of the Republic of Indonesia that is carried out by a domestic investor by use of domestic capital (Republik Indonesia, 2007). The unit used is billion rupiah.

6) Foreign Investment (FI)

Foreign investment means an investing activity to do business in the territory of the state of the Republic of Indonesia that is carried out by a foreign investor both by use of all of foreign capital and by engagement in a joint venture with a domestic investor (Republik Indonesia, 2007). The unit used is US dollar million.

7) Total Manpower

By definition (BPS, 2018), total manpower is the number of working age population (15 years and over). While working is an activity done by a person who worked for pay or assisted others in obtaining pay or profit for the duration at least one hour during the survey week. Include an unpaid worker who help an economically activity/business. The unit used is the life or person.

\subsection{Data Analysis Technique}

Data analysis used in this study was fixed effect spatial panel data with quasi maximum likelihood estimation method.

\subsubsection{Panel Data Analysis}

Panel data analysis consists of three models, namely the fixed effect model, the random effect model, and the pooled model/common effect. According to Gujarati (2004) as cited in Agusti (2015), to choose between a fixed effect model and a random effect model, it can be determined from the selection of the object of study. If the object is chosen by researcher, then the fixed effect model is the most appropriate model. While if the object is chosen randomly from the population, then a random effect model is the appropriate method to use.

\subsubsection{Spatial Analysis}

Spatial data analysis is a statistical method related to regional science, which contains the information related to location of observation. According to Anselin, 1988 as cited in Agustina (2015) the concept of spatial data consists of spatial dependence (autocorrelation) and or spatial heterogeneity. The spatial concept of dependencies is based 
on Tobler's I law, everything is related to everything else, but near things are more related than distant things (Tobler, 1970). Meanwhile, spatial heterogeneity is a condition that between locations have differences in structure, thus it is possible to have different modeling.

To measure spatial autocorrelation, the first thing that needs to be defined is "what is meant by two close observations', for which the distance unit must be determined. This distance is presented in the weighting matrix that defines the relationship between locations where the measurement is carried out. If data is collected in $N$ locations, the weight matrix will be $N \times N$ size and the diagonal will be zero.

In testing spatial dependence there are several tests that can be used to detect spatial dependence in a model, including the Moran's Index test and the Lagrange Multiplier (LM) test. The Lagrange Multiplier test provides more specific results than the Moran's Index test, because it is able to see whether the dependency that occurs is spatial lag or spatial error.

\subsubsection{Spatial Panel Data Analysis}

\section{1) Spatial Lag Panel Data Model}

Spatial Lag Model or Spatial Autoregressive Model (SAR) shows that the dependent variable depends on the independent variables observed and the dependent variable in the nearest unit/area. The following forms are spatial lag data panel models (Elhorst, 2010):

$$
y_{i t}=\rho \sum_{j=1}^{N} w_{i j} y_{j t}+x_{i t} \mathbf{\beta}+\mu_{i}+\varepsilon_{i t}
$$

where,

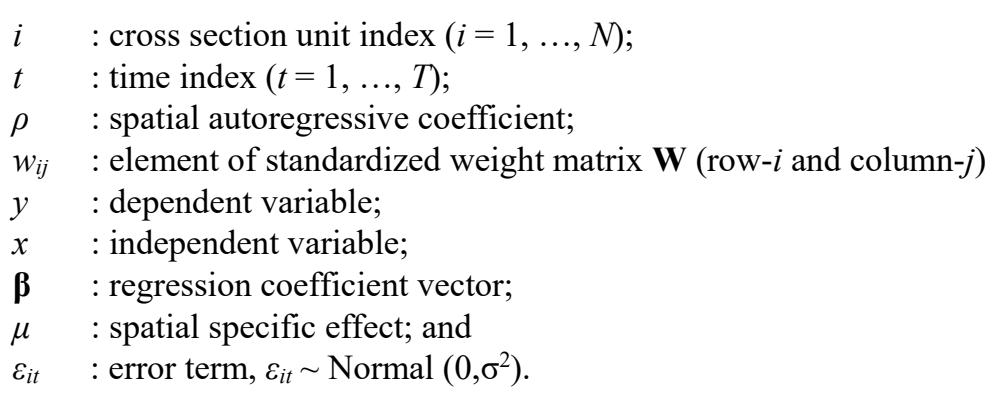

2) Spatial Error Panel Data Model

Spatial Error Model (SEM) shows that the dependent variable depends on the observed independent variable and errors that are correlated between spaces that is close to one another. The following is a model of spatial error panel data (Elhorst, 2010):

$$
y_{i t}=x_{i t} \boldsymbol{\beta}+\mu_{i}+\phi_{i t}, \text { where } \quad \phi_{i t}=\lambda \sum_{j=1}^{N} w_{i j} \phi_{j t}+\varepsilon_{i t}
$$

with $\lambda$ is the spatial autocorrelation coefficient.

\subsubsection{Quasi-Maximum Likelihood (QML)}

One of the assumptions applied in classical regression is that the error term follows the Normal distribution $\left(0, \sigma^{2}\right)$. In fact, it is often found that the error term is not normally distributed $\left(0, \sigma^{2}\right)$. If the assumption of the error is violated, then how is the interpretation of the estimator produced by the maximum likelihood method. QML can overcome this by forming a new covariance variance matrix that is more robust against distribution specification errors, otherwise known as sandwich covariance. Basically, QML still utilizes the maximum likelihood method, where for the calculation of sandwich covariance, QML uses the values generated from the maximum likelihood method. sandwich covariance $(\mathbf{S}(\boldsymbol{\theta}))$ is a modification of the Fisher information matrix $(\mathbf{F}(\boldsymbol{\theta}))$. The form of sandwich covariance is (Carroll, Ruppert, \& Stefanski, 1995, as cited in Klein \& Muthén, 2007):

$$
\mathbf{S}(\boldsymbol{\theta})=\mathbf{F}^{-1}(\boldsymbol{\theta}) \mathbf{M}(\boldsymbol{\theta}) \mathbf{F}^{-1}(\boldsymbol{\theta})
$$

where,

$$
\mathbf{F}(\boldsymbol{\theta})=-E\left[\frac{\partial^{2} \ln L(\boldsymbol{\theta})}{\partial \boldsymbol{\theta} \partial \boldsymbol{\theta}^{\mathrm{T}}}\right] \text { and } \mathbf{M}(\boldsymbol{\theta})=E\left[\frac{\partial \ln L(\boldsymbol{\theta})}{\partial \boldsymbol{\theta}} \frac{\partial \ln L(\boldsymbol{\theta})}{\partial \boldsymbol{\theta}^{\mathrm{T}}}\right]
$$


In the event of a distribution specification error (misspecification), the statistical value $t$ is obtained by the same way, which is to divide the estimated value by its standard error. But the standard error used is the square root of the diagonal matrix sandwich covariance.

\section{Results and Discussion}

\subsection{Panel Data Effect}

The object studied in this study is 33 provinces in Indonesia. In the previous chapter it was revealed that, if the object/location is determined by the researcher, the fixed effect model is the appropriate model to use. For this reason, at this initial stage, testing was carried out using the Chow test to determine whether the addition of fixed effects in the model was needed or not. Chow test was used to determine whether the fixed effect or common effect models are more appropriate to estimate panel data. With the help of the R Program, the $p$-value $\leq 0.05(\alpha)$, it means that the fixed effect model is the correct model to use. The fixed effect approach is a technique for estimating panel data based on the difference of intercepts among regions but the time invariant.

\subsection{Spatial Dependency}

Thematic maps of original local government revenue, government expenditure, domestic investment, foreign investment, total manpower, and population in 2016 are shown in Figure 2-7.

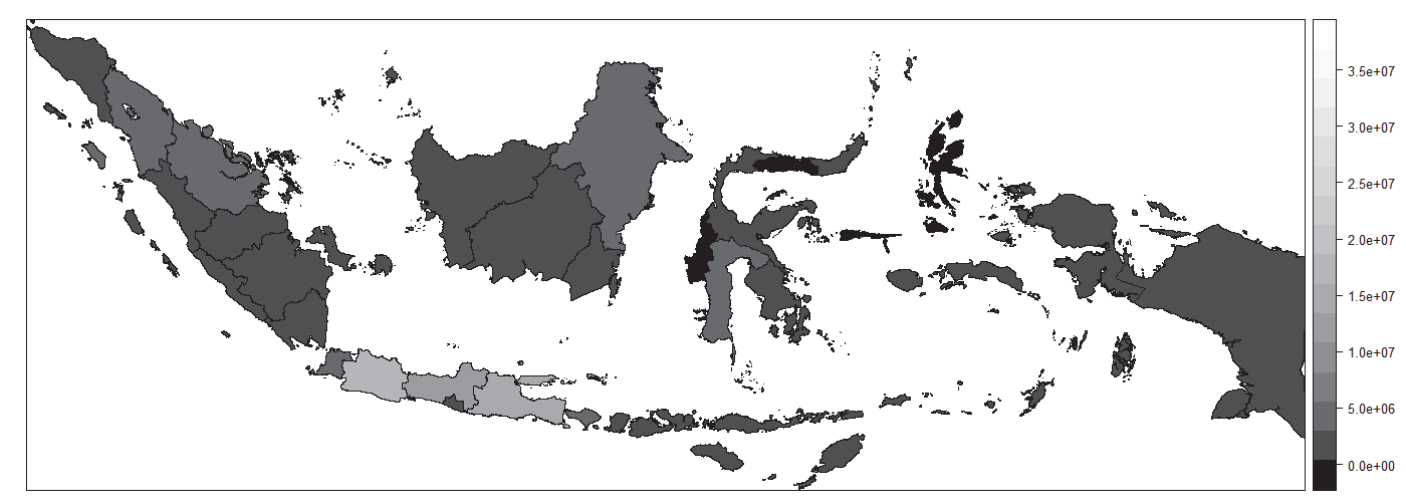

Figure 2. Thematic Map of Original Local Government Revenue 2016

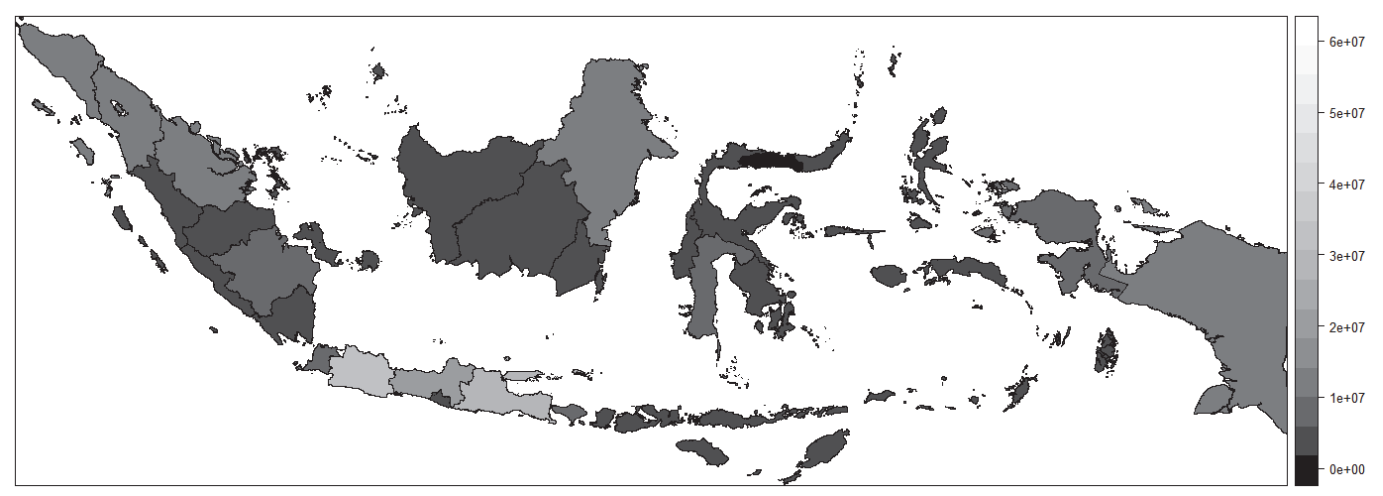

Figure 3. Thematic Map of Government Expenditure 2016 


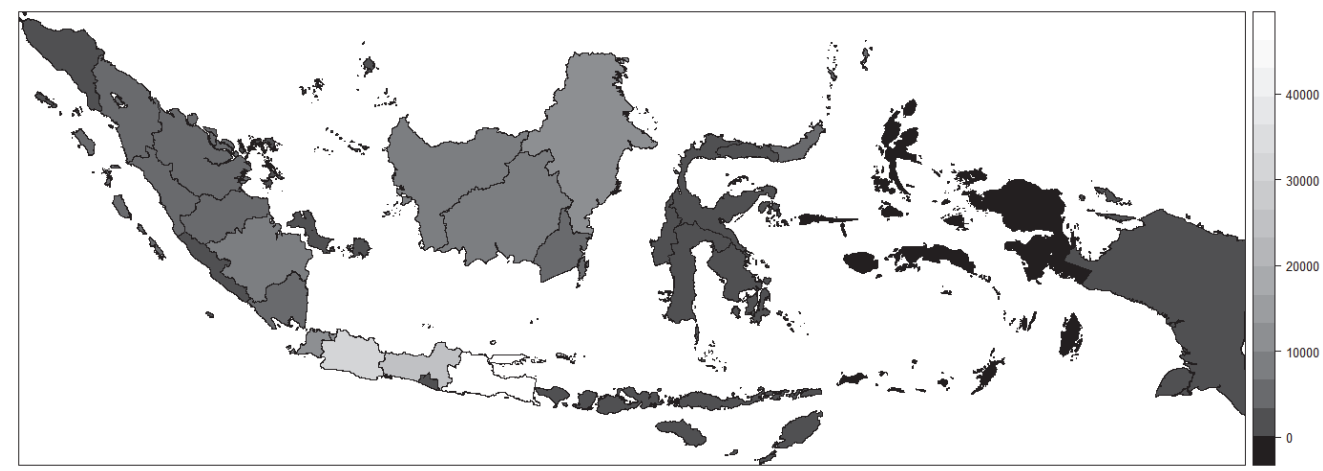

Figure 4. Thematic Map of Domestic Investment 2016

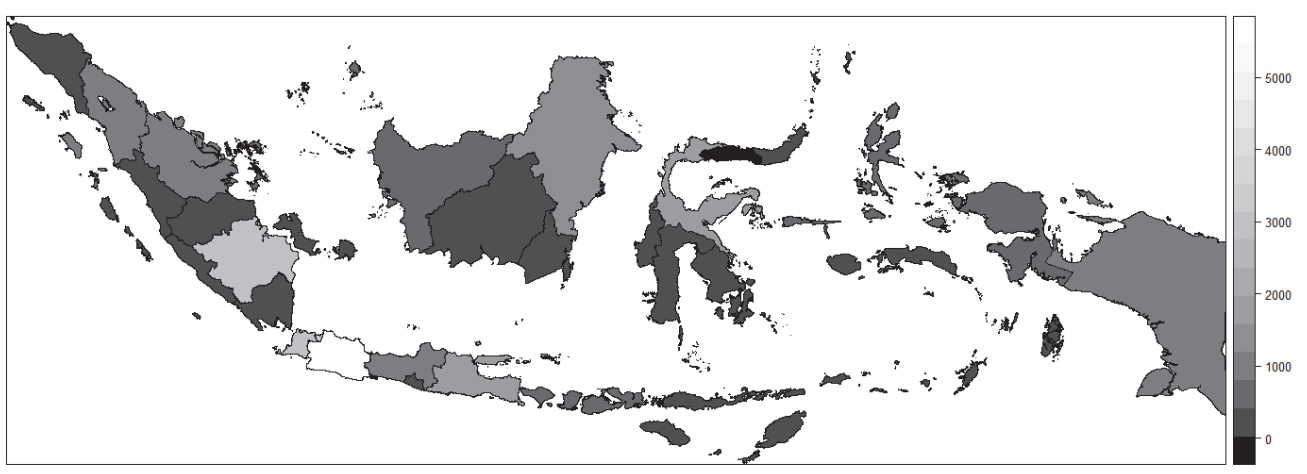

Figure 5. Thematic Map of Foreign Investment 2016

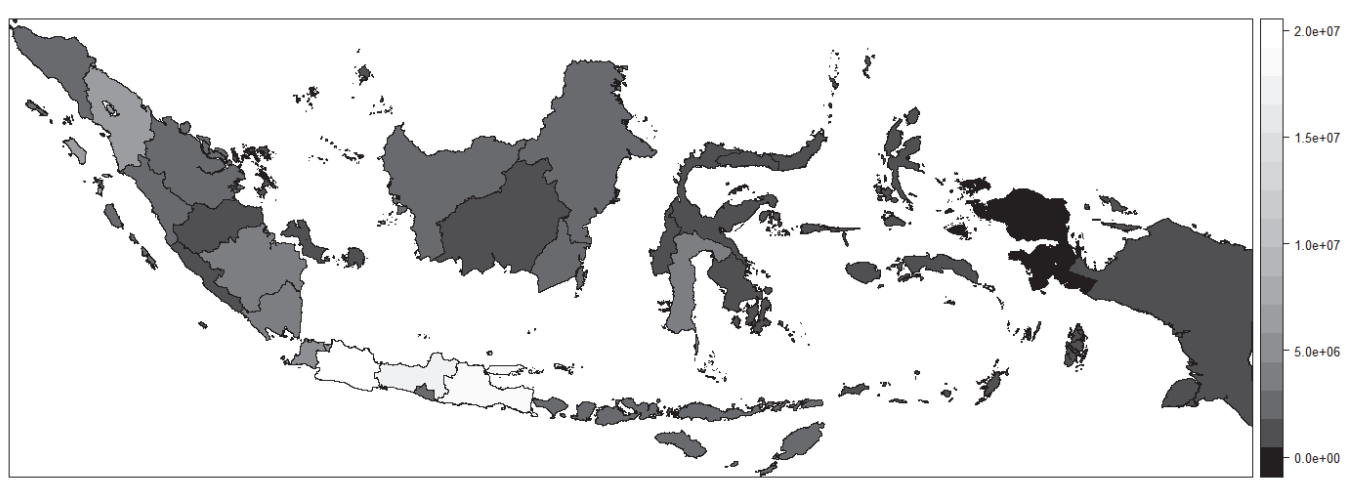

Figure 6. Thematic Map of Total Manpower 2016

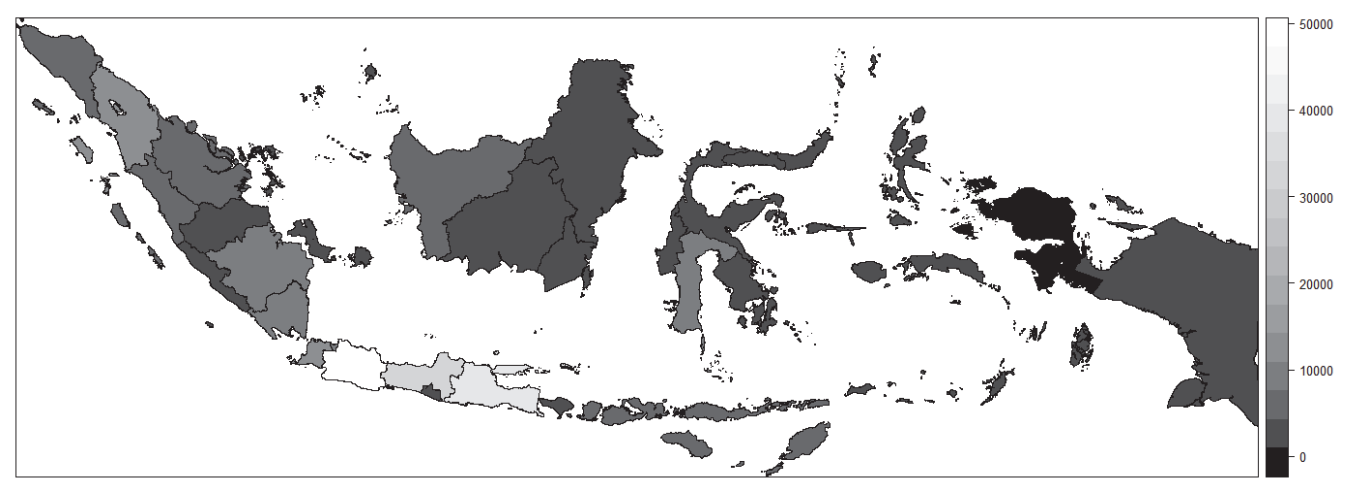

Figure 7. Thematic Map of Population 2016 
In Figure 2-7, it can be seen that the values of variables from provinces that have geographical proximity have similar values (seen from similar colors). This indicates that the value of variables in a province is not mutually independent but there is spatial dependence. But, to ascertain whether a province is not independent to other provinces, there was a spatial dependency test using the Moran's Index test and the Lagrange Multiplier (LM) test.

Table 1. Moran's Index Test Result

\begin{tabular}{ccc}
\hline Moran's Index (I) & Z(I) & P-value \\
\hline 0.1486 & 2.5460 & 0.0109 \\
\hline
\end{tabular}

Moran's Index test gave the result of rejecting the null hypothesis meaning that the data provides sufficient evidence of spatial dependency with a 95\% confidence level. Furthermore, to see whether the occurring dependency is spatial lag or spatial error, the Lagrange Multiplier test was performed.

Table 2. Lagrange Multiplier Test Result

\begin{tabular}{ccc}
\hline Model & LM & P-value \\
\hline LM-SEM & 5.8689 & $1.54 \mathrm{e}-02$ \\
LM-SAR & 12.1751 & $4.84 \mathrm{e}-04$ \\
Robust LM-SEM & 14.1497 & $1.69 \mathrm{e}-04$ \\
Robust LM-SAR & 20.4560 & $6.10 \mathrm{e}-06$ \\
\hline
\end{tabular}

At a significance level $(\alpha)$ of $5 \%$, the Lagrange Multiplier test resulted in spatial error dependence and spatial lag dependency in the regression model. Because the results of the two tests were significant, it was necessary to do a Robust LM test to find the right alternative. Table 2 shows that the LM-SAR Robust p-value was smaller than the Robust LM-SEM p-value, so the SAR model or spatial lag model was chosen.

\subsection{Spatial Panel Data Analysis}

Based on the previous panel data analysis phase, it was concluded that the chosen panel data regression model was the fixed effect model. Then at the spatial dependencies test stage above, it was obtained that there was a spatial lag dependency in the regression model. So, based on these two things, the Spatial Lag Fixed Effect Model was formed using the maximum likelihood estimation method.

The next step was testing the normality assumption using Jarque Bera's test on the residuals of the model. If the residual is normally distributed, the regression coefficient estimate test of Spatial Lag Fixed Effect Model is done using maximum likelihood. Instead, it was conducted using quasi-maximum likelihood (QML). Following are the results of the Jarque Bera test:

Table 3. Jarque Bera Test Result

\begin{tabular}{ccc}
\hline$\chi^{2}$ & Degree of Freedom & P-value \\
\hline 809.72 & 2 & $<2.2 \mathrm{e}-16$ \\
\hline
\end{tabular}

Table 3 shows that the Spatial Lag Fixed Effect Model has residuals that do not follow normal distribution because the p-value is less than $0.05(\alpha)$. So, the regression coefficient estimate test of Spatial Lag Fixed Effect Model could be done using QML. Estimation results, test statistics, and p-values are presented in Table 4.

Table 4. Parameter Significance Test Results Using Maximum Likelihood (ML) and Quasi-maximum likelihood (QML)

\begin{tabular}{lccccc}
\hline & Estimation & t-value ML & P-value ML & t-value QML & P-value QML \\
\hline Rho $(\rho)$ & -0.0168 & -0.3016 & 0.7629 & -6.4081 & $0.0000^{*}$ \\
Popuation & 39.4867 & 3.6131 & $0.0003^{*}$ & 174.7421 & $0.0000^{*}$
\end{tabular}




\begin{tabular}{lccccc} 
OLGR & 0.0164 & 4.7302 & $0.0000^{*}$ & 25.0126 & $0.0000^{*}$ \\
Government expenditure & 0.0010 & 0.4188 & 0.6754 & 4.0167 & $0.0001^{*}$ \\
Domestic investment & 1.8443 & 2.6754 & $0.0075^{*}$ & 3.7877 & $0.0002^{*}$ \\
Foreign investment & 2.9839 & 0.8042 & 0.4213 & 2.0246 & $0.0429^{*}$ \\
Total manpower & 0.0003 & 0.3057 & 0.7598 & 0.9585 & 0.3378 \\
\hline
\end{tabular}

Quasi-maximum likelihood test results show that the variables that have a significant effect on GRDP at constant prices partially were population, original local government revenue (OLGR), government expenditure, domestic investment, and foreign investment. In other words, only total manpower variable that do not partially have a significant effect on GRDP at constant prices.

Furthermore, the establishment of the Spatial Lag Fixed Effect Model using five significant variables was conducted with the results of parameter estimation shown in Table 5.

Table 5. Estimation Results

\begin{tabular}{lrlr}
\hline & Estimation & & Estimation \\
\hline Rho $(\rho)$ & -0.0272 & Government expenditure & 0.0011 \\
Population & 39.5991 & Domestic investment & 1.9801 \\
Original local government revenue & 0.0163 & Foreign investment & 2.9065 \\
\hline
\end{tabular}

To determine a model with six variables (full model) or a better five model (reduced model), a goodness of fit test was performed. Goodness of fit test was done by calculating the AIC (Akaike Information Criterion) value from both models.

Table 6 Akaike Information Criterion (AIC)

\begin{tabular}{lc}
\hline \multicolumn{1}{c}{ Model } & AIC \\
\hline Full Model & 5177.459 \\
Reduced Model & 5176.040 \\
\hline
\end{tabular}

The results in Table 6 show that a smaller AIC value was on Reduced Model or Spatial Lag Fixed Effect Model with five variables. So it can be concluded that the Spatial Lag Fixed Effect Model with variables of population, original local government revenue, government expenditure, domestic investment, and foreign investment were better used to model GRDP at constant prices in Indonesia for 2010-2016 periods. The following is the intended Spatial Lag Fixed Effect Model:

$$
\begin{aligned}
\hat{y}_{i t}= & -0.0272 \sum_{j=1}^{33} w_{i j} \hat{y}_{j t}-110791+39.5991 \text { population }_{i t}+0.0163 O \text { LGR }_{i t}+0.0011 G E_{i t}+1.9801 D I_{i t} \\
& +2.9065 F I_{i t}+\mu_{i}
\end{aligned}
$$

where,

i : $1,2, \ldots, 33$;

$t \quad: 2010,2012, \ldots, 2016 ;$ and

$\mu_{i} \quad$ : spatial specific effect (see Table 7). 
Table 7. Spatial Fixed Fffects for Each Province

\begin{tabular}{lrlrlr}
\hline Province & Estimation & Province & Estimation & Province & Estimation \\
\hline Bali & 34222.4 & East Java & -468885.6 & NTT & -46184.2 \\
Bangka Belitung & 95494.0 & West Kal & -313.1 & Papua & 86131.8 \\
Banten & -90540.9 & South Kal & 14714.9 & Riau & 240402.6 \\
Bengkulu & 63636.1 & Central Kal & 64054.0 & West Sulawesi & 82890.8 \\
DI Yogyakarta & 43595.0 & East Kal & 309796.3 & South Sulawesi & -54225.7 \\
DKI Jakarta & 529652.9 & Kepri & 161473.0 & Central Sulawesi & 54679.8 \\
Gorontalo & 82474.5 & Lampung & -55966.8 & South East Sulawesi & 67088.0 \\
Papua Barat & 115064.2 & Maluku & 62290.1 & North Sulawesi & 63412.8 \\
Jambi & 72435.8 & Malut & 81046.4 & West Sumatera & 12447.5 \\
West Java & -847982.6 & NAD & 1222.8 & South Sumatera & -17824.8 \\
Central Java & -630149.1 & NTB & -19096.2 & North Sumatera & -107056.5 \\
\hline
\end{tabular}

From the results of spatial regression with panel data, it was revealed that the variables of population, original local government revenue, government expenditure, domestic investment, and foreign investment in 33 provinces in Indonesia had a positive and significant effect on GRDP at constant prices. This is in line with the hypothesis stated earlier. The interpretation of the model above is as follows:

1) A 1000 population increase will increase the GRDP at constant prices by 39.60 billion rupiah if the value of other variables remains

2) A one million rupiah increase in original local government revenue will increase the GRDP at constant prices by 16.3 million rupiah if the value of other variables remains

3) A one million rupiah increase in government expenditure will increase the GRDP at constant prices by 1.1 million rupiah if the value of other variables remains.

4) A one billion rupiah increase of domestic investment will increase the GRDP at constant prices by 1.98 billion rupiahs if the value of other variables remains.

5) A one million US\$ foreign investment increase will increase the GRDP at constant prices by almost 2.91 billion rupiah if the value of other variables remains

The following is an example of a Spatial Lag Fixed Effect Model for Bali Province $(i=1)$. Bali Province has two closest neighbors namely East Java Province $(i=12)$ and West Nusa Tenggara Province $(i=22)$.

$$
\begin{aligned}
\hat{y}_{(1) t}= & -0.0272\left(\frac{1}{2} \hat{y}_{(12) t}+\frac{1}{2} \hat{y}_{(22) t}\right)-110791+39.5991 \text { population }_{(1) t}+0.0163 O \text { LGR }_{(1) t}+0.0011 G E_{(1) t} \\
& +1.9801 D I_{(1) t}+2.9065 F I_{(1) t}+34222.4 \\
\hat{y}_{(1) t}= & -0.0136\left(\hat{y}_{(12) t}+\hat{y}_{(22) t}\right)-76568.6+39.5991 \text { population }_{(1) t}+0.0163 \text { OLGR }_{(1) t}+0.0011 G E_{(1) t} \\
& +1.9801 D I_{(1) t}+2.9065 F I_{(1) t}
\end{aligned}
$$

\section{Conclusion}

Based on analysis result and discussion it can be concluded that:

1) The appropriate panel data regression model to be used is fixed effect model.

2) Spatial analysis on GRDP data and the affecting factors in Indonesia in 2010-2016 indicated a spatial lag dependency in regression model.

3) A fixed effect in residual spatial lag model formed was not normally distributed. So, a parameter significancy test was taken using quasi-maximum likelihood (QML).

4) A significant variables toward GRDP at constant prices partially is the number of population, original local government revenue, government expenditure, domestic investment, and foreign investment. In other words, only the total manpower variable that partially does not have significant impact toward GRDP at constant prices.

5) Spatial Lag Fixed Effect Model for GRDP at constant prices modelling in Indonesia 2010-2016 is: 


$$
\hat{y}_{i t}=-0.0272 \sum_{j=1}^{33} w_{i j} \hat{y}_{j t}-110791+39.5991 \text { population }_{i t}+0.0163 O L G R_{i t}+0.0011 G E_{i t}+1.9801 D I_{i t}
$$

\section{Acknowledgments}

$$
+2.9065 F I_{i t}+\mu_{i}
$$

The author would like to thank BPS-Statistics Indonesia and the Applied Statistics Study Program, Department of Statistics, Faculty of Mathematics and Natural Sciences (FMIPA), Universitas Padjajaran, Bandung for their support.

\section{References}

Abbas, Q., Akbar, S., Nasir, A. S., AmanUllah, H., \& Naseem, M. A. (2011). Impact of Foreign Direct Investment on Gross Domestic Product. Global Journal of Management and Business Research, 11(8), 34-40.

Adiati, T. (2016). Pemodelan Regresi Spasial dengan Pendekatan Bootstrap Residual (Studi Kasus Pertumbuhan Ekonomi di Provinsi Sulawesi Selatan Tahun 2013) (Unpublished master's thesis). Universitas Padjadjaran, Bandung.

Agusti, R. (2015). Pemodelan Data Panel Kemiskinan Tak Seimbang di Pulau Jawa dengan Model Spasial Durbin (Master's thesis). Sekolah Pascasarjana Institut Pertanian Bogor, Bogor. Retrieved from http://repository.ipb.ac.id/jspui/bitstream/123456789/79002/1/2015rag.pdf

Agustina. (2015). Model Panel Autoregresif Spasial dengan Fixed Effect pada Tingkat Partisipasi Angkatan Kerja Perempuan se-Jawa Barat (Master's thesis). Universitas Padjadjaran. Retrieved from https://lib.unpad.ac.id//index.php?p=show_detail\&id=73770

Aji, C. A. W., Mukid, M. A., \& Yasin, H. (2014). Analisis Faktor-Faktor Yang Mempengaruhi Laju Pertumbuhan Penduduk Kota Semarang Tahun 2011 Menggunakan Geographically Weighted Logistic Regression. Jurnal Gaussian, 3(2), 161-171.

Boldeanu, F. T., \& Constantinescu, L. (2015). The main determinants affecting economic growth. Bulletin of the Transilvania University of Braşov, 8(2), 329-338.

BPS. (2018). Badan Pusat Statistik. Retrieved from https://www.bps.go.id/

Chalid, P. (2015). Teori Pertumbuhan. In Teori dan Isu Pembangunan. Jakarta: Universitas Terbuka.

Darlin, E. (2012). Analisis Faktor-Faktor yang Mempengaruhi Pertumbuhan Ekonomi Indonesia Tahun 1979-2008. Jurnal Lentera Bisnis, 1(2), 51-77.

Diputra, T. F., Sadik, K., \& Angraini, Y. (2012). Pemodelan Data Panel Spasial dengan Dimensi Ruang dan Waktu. FSK : Indonesian Journal of Statistics, 17(1), 6-14.

Divya, K. H., \& Devi, V. R. (2014). A Study on Predictors of GDP: Early Signals. Procedia Economics and Finance, 11, 375-382. https://doi.org/10.1016/S2212-5671(14)00205-6

Edi, Y. S. (2012). Quasi-Maximum Likelihood untuk Regresi Panel Spasial (Studi Kasus: Laju Pertumbuhan Ekonomi Kabupaten/Kota di Provinsi Jawa Timur 2007-2009) (Master's thesis). Institut Teknologi Sepuluh Nopember, Surabaya. Retrieved from http://digilib.its.ac.id/ITS-Master-3100012045863/19013

Elhorst, J. P. (2010). Spatial Panel Data Models. In M. M. Fischer \& A. Getis (Eds.), Handbook of Applied Spatial Analysis (pp. 377-407). Berlin, Heidelberg: Springer Berlin Heidelberg. https://doi.org/10.1007/978-3-64203647-7_19

Eliana, R. (2016). Penerapan Model Spasial Data Panel dengan Generalized Method Of Moments pada Data Produk Domestik Regional Bruto (PDRB) (Master's thesis). Universitas Padjadjaran, Bandung. Retrieved from https://lib.unpad.ac.id//index.php?p=show_detail\&id=73807

Haviliana, M. (2017). Interaksi Spasial Perekonomian dan Ketenagakerjaan Provinsi-Provinsi di Pulau Sumatera Tahun 2001-2015 (Skripsi). Universitas Lampung, Bandar Lampung. Retrieved from http://digilib.unila.ac.id/29177/

Heryanti, Y., Junaidi, \& Yulmardi. (2014). Interaksi Spasial Perekonomian dan Ketenagakerjaan Antar Kabupaten/ Kota di Provinsi Jambi. Jurnal Perspektif Pembiayaan Dan Pembangunan Daerah, 2(2), 99-106.

Hikmah, Y. (2017). Pemodelan Panel Spasial pada Data Kemiskinan di Provinsi Papua, 17(1), 15. 
Jain, D., Nair, K. S., \& Jain, V. (2015). Factors Affecting GDP (Manufacturing, Services, Industry): An Indian Perspective. Annual Research Journal of SCMS Pune, 3, 38-56.

Kira, A. R. (2013). The Factors Affecting Gross Domestic Product (GDP) in Developing Countries: The Case of Tanzania. European Journal of Business and Management, 5(4), 148-158.

Klein, A. G., \& Muthén, B. O. (2007). Quasi-Maximum Likelihood Estimation of Structural Equation Models With Multiple Interaction and Quadratic Effects. Multivariate Behavioral Research, 42(4), 647-673. https://doi.org/10.1080/00273170701710205

LeSage, J. P., \& Pace, R. K. (2004). INTRODUCTION. In Advances in Econometrics (Vol. 18, pp. 1-32). Bingley: Emerald (MCB UP). https://doi.org/10.1016/S0731-9053(04)18013-4

LeSage, J. P., \& Pace, R. K. (2008). Spatial Econometric Modeling of Origin-Destination Flows. Journal of Regional Science, 48(5), 941-967. https://doi.org/10.1111/j.1467-9787.2008.00573.x

LeSage, J. P., \& Pace, R. K. (2009). Introduction to Spatial Econometrics. London: Chapman \& Hall.

Lestari, W. S. (2015). Analisis Data Spasial Menggunakan Metode Bayesian Geographically Weighted Regression (Studi Kasus Data PDRB per Kapita di Provinsi Jawa Timur) (Master's thesis). Universitas Padjadjaran, Bandung. Retrieved from https://lib.unpad.ac.id//index.php?p=show_detail\&id=73702

Lim, U., \& Kim, D. (2015). Toward Sustainable Economic Growth: A Spatial Panel Data Analysis of Regional Income Convergence in US BEA Economic Areas. Sustainability, 7(8), 9943-9959. https://doi.org/10.3390/su7089943

Marsono. (2013). Pemodelan Pengangguran Terbuka di Indonesia dengan Pendekatan Ekonometrika Spasial Data Panel (Unpublished master's thesis). Institut Teknologi Sepuluh Nopember, Surabaya.

Mildino, S. (2011). Pemilihan Model Fixed Effects dan Random Effects pada Pemodelan Ekonometrika Spasial Data Panel (Studi Kasus: Pemodelan Indeks Rasio Gini Propinsi Di Pulau Jawa) (Master's thesis). Institut Teknologi Sepuluh Nopember, Surabaya. Retrieved from http://digilib.its.ac.id/ITS-Master$3100011042393 / 15217$

Millo, G., \& Piras, G. (2012). splm: Spatial Panel Data Models in R. Journal of Statistical Software, 47(1), 1-39. https://doi.org/10.18637/jss.v047.i01

Muchlisoh, S. (2008). Model Regresi Data Panel dengan Korelasi Error Spasial (Studi: Pengaruh Pertumbuhan Ekonomi dan Inflasi terhadap Kemiskinan di Indonesia) (Master's thesis). Institut Teknologi Sepuluh Nopember, Surabaya. Retrieved from http://digilib.its.ac.id/ITS-Master-3100008031162/4035

Muchtolifah. (2010). Ekonomi Makro. Surabaya: Unesa University Press.

Nabilah, D., \& Setiawan. (2016). Pemodelan Pertumbuhan Ekonomi Indonesia Menggunakan Data Panel Dinamis dengan Pendekatan Generalized Method of Moment Arellano-Bond. Jurnal Sains dan Seni ITS, 5(2), 205 210.

Ou, B., Zhao, X., \& Wang, M. (2015). Power of Moran's I Test for Spatial Dependence in Panel Data Models with Time Varying Spatial Weights Matrices. Journal of Systems Science and Information, 3(5), 463-471. https://doi.org/10.1515/JSSI-2015-0463

Pambudi, E. W., \& Miyasto. (2013). Analisis Pertumbuhan Ekonomi dan Faktor-Faktor Yang Mempengaruhi (Kabupaten/Kota di Provinsi Jawa Tengah). Diponegoro Journal of Economics, 2(2), 1-11.

Prariesa, D. (2018). Peramalan Produk Domestik Bruto (PDB) Triwulanan Indonesia dengan Model Hybrid Singular Spectrum Analysis (SSA) - ARIMA (Unpublished master's thesis). Universitas Padjadjaran, Bandung.

Pratama, R., Kusnandar, D., \& Rizki, S. W. (2018). Pendekatan Ekonometrika Panel Spasial untuk Pemodelan Produk Domestik Regional Bruto Di Kalimantan Barat. Buletin Ilmiah Matematika, Statistika dan Terapannya (Bimaster), 7(1), 1-8.

Prok, K. (2015). Faktor-Faktor yang Mempengaruhi Pertumbuhan Ekonomi Sulawesi Utara Selama Periode Otonomi Daerah 2001-2013. Jurnal Berkala Ilmiah Efisiensi, 15(3), 1-15.

Purwaningsih, T. (2014). Kajian Pengaruh Matriks Pembobot Spasial dalam Model Data Panel Spasial (Master's thesis). Sekolah Pascasarjana Institut Pertanian Bogor, Bogor. Retrieved from https://repository.ipb.ac.id/jspui/bitstream/123456789/73014/1/2014tpu.pdf

Rahardja, P., \& Manurung, M. (2014). Teori Ekonomi Makro Suatu Pengantar (5th ed.). Jakarta: Lembaga Penerbit Fakultas Ekonomi Universitas Indonesia. 
Republik Indonesia. (2007). Indonesian Law No. 25 of 2007 on Capital Investment.

Sartika, W., Susetyo, B., \& Syafitri, U. D. (2017). Spatial panel data models of aquaculture production in West Sumatra province with random-effects. American Institute of Physics. https://doi.org/10.1063/1.4979424

Siswanto, Hamur, A. S., \& Arisona, D. C. (2017). Pemodelan Data Panel Kemiskinan di Provinsi Nusa Tenggara Timur dengan Menggunakan Spasial Durbin Model (Paper). Sekolah Pascasarjana Institut Pertanian Bogor, Bogor. Retrieved from http://www.academia.edu/31971740/PEMODELAN_SPASIAL_DURBIN_MODEL_UNTUK_DATA_KE MISKINAN_DI_PROVINSI_NTT

Suindyah D, S. (2011). Pengaruh Investasi, Tenaga Kerja dan Pengeluaran Pemerintah Terhadap Pertumbuhan Ekonomi di Propinsi Jawa Timur. EKUITAS (Jurnal Ekonomi dan Keuangan), 15(4), 477-500. https://doi.org/10.24034/j25485024.y2011.v15.i4.2312

Sumardi - 2016 - Bayesian Model Averaging (BMA) dalam Pemodelan PDR.pdf. (n.d.).

Sumardi, Y. (2016). Bayesian Model Averaging (BMA) dalam Pemodelan PDRB ADHK di Indonesia Tahun 2013 (Master's thesis). Universitas Padjadjaran, Bandung. Retrieved from https://lib.unpad.ac.id//index.php?p=show_detail\&id=73711

Sutomo, S. (2015). Sistem Data dan Perangkat Analisis Ekonomi Makro. Bandung: CorBooks.

Tamara, I., Ispriyanti, D., \& Prahutama, A. (2016). Pembentukan Model Spasial Data Panel Fixed Effect Menggunakan GUI MATLAB. Jurnal Gaussian, 5(3), 10.

Tobler, W. R. (1970). A Computer Movie Simulating Urban Growth in the Detroit Region. Economic Geography, 46, 234. https://doi.org/10.2307/143141

Widjajanta, B., Widyaningsih, A., \& Tanuatmodjo, H. (2009). Mengasah Kemampuan Ekonomi 2. Jakarta: Pusat Perbukuan Departemen Pendidikan Nasional.

\section{Copyrights}

Copyright for this article is retained by the author(s), with first publication rights granted to the journal.

This is an open-access article distributed under the terms and conditions of the Creative Commons Attribution license (http://creativecommons.org/licenses/by/4.0/). 